\title{
Book Review: A Naturalist in Indian Territory: The Journals of S. W. Woodhouse
}

Barbara Keener

Unknown

Follow this and additional works at: https://scholarworks.sfasu.edu/ita

Part of the American Material Culture Commons, Archaeological Anthropology Commons, Environmental Studies Commons, Other American Studies Commons, Other Arts and Humanities Commons, Other History of Art, Architecture, and Archaeology Commons, and the United States History Commons

Tell us how this article helped you.

This Article is brought to you for free and open access by the Center for Regional Heritage Research at SFA ScholarWorks. It has been accepted for inclusion in Index of Texas Archaeology: Open Access Gray Literature from the Lone Star State by an authorized editor of SFA ScholarWorks. For more information, please contact cdsscholarworks@sfasu.edu. 
Book Review: A Naturalist in Indian Territory: The Journals of S. W. Woodhouse

Creative Commons License

(c) $)(1)$ (9)

This work is licensed under a Creative Commons Attribution-NonCommercial 4.0 International License 


\section{BOOK REVIEW}

A Naturalist in Indian Territory: The Journals of S. W. Woodhouse, 1849-1850, edited and annotated by John S. Tomer and Michael J. Broadhead. Norman: The University of Oklahoma Press. 304 pages, notes, appendix, bibliography, index. Hard cover edition 1992. Volume 72 in The American Exploration and Travel Series.

Samuel Washington Woodhouse, a Philadelphia physician and avid ornithologist, was appointed surgeon-naturalist of two expeditions to survey the Creek-Cherokee boundary in Indian Territory. The Creek boundary expedition that Woodhouse was asked to join was a Corps of Topographical Engineers survey party sent to survey and mark the northern and western boundaries of the Creek Indian lands in Indian Territory to comply with the requirements of the Creek Treaty of 1845 . The usual purpose of these surveys was to map the land, describe its topography, and learn about its native inhabitants. Later objectives were to establish roads and to set boundaries as the westward movement of settlers began, in addition to observing and gathering specimens of the animals, plants, and minerals of the West. Woodhouse served on both expeditions of the survey, the first in 1849 under Capt. Lorenzo Sitgreaves and the second under Lt. Israel Carle Woodruff in 1850.

While traveling, Woodhouse filled three journals with his impressions and observations of the people he encountered, and of the specimens he collected for the Smithsonian Institution, National Museum of Natural History. The first diary, now in the Historical Society of Pennsylvania archives, covers the period from April 26 through June 19, 1849. The second and third diaries are both now in the library of the Academy of Natural Sciences of Philadelphia. The second journal contains entries from June 20 through December 29, 1849; the third continues from June 12 through October 8,1850 .
Until the publication of this book, Woodhouse's early work as a professional naturalist in Indian Territory has been little noticed and seldom cited in literature. The editors explain that this deficit is a result partly of the paucity of notice in the literature of the Creek Indian boundary survey itself. His later work is best known from his natural history report in Lorenzo Sitgreave's Report of an Expedition Down the Zuni and Colorado Rivers.

The editors of this book have done an impressive job of researching and compiling the information necessary to write the introduction and the notes which accompany the journals. The detailed introduction and clarifying notes reveal that Woodhouse was very bad at spelling, grammar, and punctuation. He also seems to have misidentified almost every specimen he collected. But aside from these small problems, the end notes provide an excellent explanation of the things and people Woodhouse talks about, including exact locations of where the expedition camped, complete with section, township, and range. Maps, pictures, and actual sketches Woodhouse made in the journals are scattered throughout the book and explained in detail by the editors.

John S. Tomer is a Research Associate at the Oklahoma Museum of Natural History, an experienced ornithologist, and the author of many articles on Oklahoma birds. Michael J. Brodhead is a Professor of History at the University of Nevada, Reno, and a specialist on the exploration of the American West and the study of its natural history. These two editors make this book a must for anyone interested in the early historic environment of the American West and in the Native American condition on the 19th century American frontier.

\section{Reviewed by Barbara Keener}

NOTE: This book won two awards for the year 1993. They are the (1) Choice Outstanding Academic Book Award of 1993 presented by Choice Magazine, and (2) Best Book in Oklahoma History for 1993 given by the Oklahoma Historical Society. 